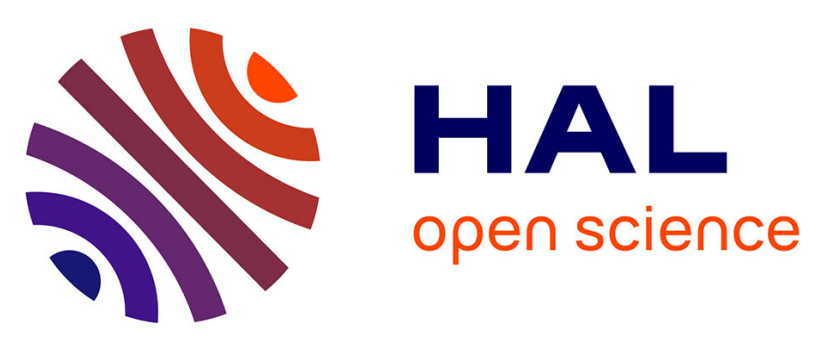

\title{
Relative contributions of biomass burning emissions and atmospheric transport to carbon monoxide interannual variability
}

\author{
S. Szopa, D. Hauglustaine, P. Ciais
}

\section{- To cite this version:}

S. Szopa, D. Hauglustaine, P. Ciais. Relative contributions of biomass burning emissions and atmospheric transport to carbon monoxide interannual variability. Geophysical Research Letters, 2007, 34 (18), 10.1029/2007GL030231 . hal-02926770

\section{HAL Id: hal-02926770 \\ https://hal.science/hal-02926770}

Submitted on 10 Dec 2020

HAL is a multi-disciplinary open access archive for the deposit and dissemination of scientific research documents, whether they are published or not. The documents may come from teaching and research institutions in France or abroad, or from public or private research centers.
L'archive ouverte pluridisciplinaire HAL, est destinée au dépôt et à la diffusion de documents scientifiques de niveau recherche, publiés ou non, émanant des établissements d'enseignement et de recherche français ou étrangers, des laboratoires publics ou privés. 


\title{
Relative contributions of biomass burning emissions and atmospheric transport to carbon monoxide interannual variability
}

\author{
S. Szopa ${ }^{1,2}$ D. A. Hauglustaine, ${ }^{1}$ and P. Ciais ${ }^{1}$ \\ Received 31 March 2007; revised 26 June 2007; accepted 17 July 2007; published 22 September 2007.
}

[1] Biomass burning is an important source of greenhouse gases and of ozone precursors such as $\mathrm{CO}$. Recent analyses combining the use of satellite data and of ecosystem models showed that wild fire emissions are subject to a large interannual variability. In this study, NOAA/ESRL CO surface measurements are used in conjunction with the results from the LMDz-INCA global chemistry-transport model and analyzed over the 1997-2001 period in order to quantify the relative contributions of biomass burning emissions and of climate to the $\mathrm{CO}$ interannual variability (IAV). Over the considered five year period, the mean CO IAV was found to be about $11 \%$ for stations far from regional pollution and $4.5 \%$ for Antarctic stations. At both southern and northern high latitude stations, the CO IAV is controlled almost equally by variations in biomass burning emissions and atmospheric meteorology. On the contrary, meteorological variability prevails in the tropics, where it explains $50 \%$ to $90 \%$ of the CO IAV. Variability in longrange transport and climate is thus the dominant process controlling the $\mathrm{CO}$ interannual variability, except during specific episodes, such as the intense fires associated with the 1997-1998 El Niño event. Citation: Szopa, S., D. A. Hauglustaine, and P. Ciais (2007), Relative contributions of biomass burning emissions and atmospheric transport to carbon monoxide interannual variability, Geophys. Res. Lett., 34, L18810, doi:10.1029/2007GL030231.

\section{Introduction}

[2] The atmospheric chemical cycles of carbon monoxide (CO), methane $\left(\mathrm{CH}_{4}\right)$ and ozone $\left(\mathrm{O}_{3}\right)$ are intimately intertwined and control the oxidizing capacity of the troposphere. $\mathrm{CH}_{4}$ and $\mathrm{O}_{3}$ contribute together about $30 \%$ to the radiative forcing of climate since pre-industrial times [Ramaswamy et al., 2001]. Both $\mathrm{CH}_{4}$ and $\mathrm{CO}$ are precursors of tropospheric $\mathrm{O}_{3}$ and control its background levels at the global scale. The distributions of $\mathrm{CO}$ and of $\mathrm{CH}_{4}$ are affected by both changes in meteorology, surface emissions and photochemistry and, in particular, the level of hydroxyl radicals $(\mathrm{OH})$. As a consequence, their abundance at the surface exhibits a strong interannual variability (IAV). Two main processes controlling the $\mathrm{CO}$ and $\mathrm{CH}_{4} \mathrm{IAV}$ are their long-range transport in the atmosphere and their emissions through biomass burning. In particular, abnormally high growth rates of atmospheric $\mathrm{CO}$ and $\mathrm{CH}_{4}$ are usually

\footnotetext{
${ }^{1}$ Laboratoire des Sciences du Climat et de l'Environnement, Institut Pierre-Simon Laplace, CEA, CNRS, UVSQ, Gif-sur-Yvette, France.

${ }^{2}$ Also at Laboratoire de Météorologie Dynamique, Institut Pierre-Simon Laplace, Ecole Polytechnique, Palaiseau, France.
}

Copyright 2007 by the American Geophysical Union. 0094-8276/07/2007GL030231 associated with El Niño events [Langenfelds et al., 2002; Bousquet et al., 2006].

[3] The distribution and variability of biomass burning emissions is now better characterized, thanks to the combined use of global satellite observations (fire counts and burned areas) and terrestrial ecosystem models [van der Werf et al., 2006]. van der Werf et al. [2004] optimized regional fire emissions of various carbon containing species against surface atmospheric $\mathrm{CO}$ observations, and inferred for the 1997-1998 El Niño event a fire emission anomaly of $2.1 \pm 0.8 \mathrm{PgC}$ in excess of the 5 year averaged flux of $3.53 \mathrm{PgC} \cdot \mathrm{yr}^{-1}$. This anomaly is distributed between southeast Asia, central and south America and boreal regions. However, they neglected the interannual variability of atmospheric transport and therefore attributed all the $\mathrm{CO}$ interannual variations to biomass burning emissions.

[4] The objective of this study is to assess the relative contributions of interannual variations in meteorology versus wild-fire emissions to the $\mathrm{CO}$ concentrations over the 1997-2001 period. We use weekly CO flask measurements from the global cooperative NOAA/ESRL network and a global chemistry transport model driven by interannually varying wind fields. The period of interest includes the El Niño event having the second largest ENSO index of the 20th century in 1997-1998 [Wolter and Timlin, 1998] followed by wetter and cooler La Nina conditions in 1998-2000. Such a strong global climate event is well suited to analyze the variability of $\mathrm{CO}$ under a wide range of meteorological conditions. Furthermore, over the period of interest, we also benefit from the availability of homogeneous and consistent datasets for both meteorology and biomass burning emissions.

\section{Measurements and Modeling Set-Up}

[5] We analyzed CO flask measurements from 36 groundlevel sites. Details of the sampling network and analytical procedures are given by Dlugokencky et al. [1994, 2005] and Novelli et al. [1998, 2003]. At each site, the flask time series were decomposed into the sum of a smoothly varying mean seasonal cycle and its high-frequency residuals using the curve fitting method of Thoning et al. [1989].

[6] Simulations are performed using the global chemistryclimate model LMDz-INCA [Hauglustaine et al., 2004]. LMDz is an atmospheric general circulation model used to simulate the transport of trace species and coupled on-line to the chemistry and aerosols module INCA. The surface emissions and atmospheric oxidation reactions of $\mathrm{CH}_{4}$, $\mathrm{CO}$ and non-methane hydrocarbons are documented by Folberth et al. [2006]. Hydroxyls are computed on-line and thus vary from year to year. In this study, the model is run with 19 hybrid levels from the surface to $3 \mathrm{hPa}$ at a 
horizontal resolution of $2.5^{\circ}$ in latitude and $3.75^{\circ}$ in longitude. Wind and temperature fields are relaxed towards the ECMWF ERA40 reanalysis [Uppala et al., 2005] with a time constant of 6 hours. The reanalysis ended in August 2002; therefore we limit our study to the 1997-2001 period in order to prevent discontinuities and inconsistencies in the meteorology-driven atmospheric transport fields.

[7] We used the recent GFED-v2 global biomass burning monthly emission dataset [van der Werf et al., 2006]. In GFED-v2, wildfire carbon emissions were mapped over the period 1997-2001 using remotely sensed fire counts from TRMM-VIRS in the tropics [Giglio et al., 2003] and from ERS-ATSR [Arino et al., 1999] elsewhere. These satellite data are used in combination with EOS-MODIS [Justice et al., 2002] burned area and are fed into the CASA terrestrial ecosystem model [Potter et al., 1993]. Emission factors from Andreae and Merlet [2001] are used to derive the emissions of $\mathrm{CO}$, nitrogen oxides and hydrocarbons.

[8] Two simulations were performed using the LMDz-INCA model: BB_CLIM uses mean climatological emissions over 8 years (1997-2004), and BB_VAR relies on interannually variable fire emissions. The mean global $\mathrm{CO}$ biomass burning emissions are $433 \mathrm{Tg} / \mathrm{yr}$ (see details in Table S1 of the auxiliary material). ${ }^{1}$ These savanna, forest and peat fires account for approximately $40 \%$ of the total $\mathrm{CO}$ emissions. In the BB_VAR simulation, the $\mathrm{CO}$ anomalous emission during $199 \overline{8}$ is $36 \%$ higher than the long-term mean (i.e. $586 \mathrm{Tg} \mathrm{CO}$ ).

\section{Results}

[9] The observed and simulated $\mathrm{CO}$ time series are displayed in Figure S1 for all the NOAA/ERSL sites. At high latitudes in both hemispheres, $\mathrm{CO}$ shows similar seasonal cycles and IAV. Over the rest of the globe, CO variations differ from one site to another in terms of their seasonal cycle amplitude, phase and high frequency variability. We selected 6 stations having contrasting seasonal cycles in order to analyze the contribution of biomass burning emissions and meteorological changes to the measured $\mathrm{CO}$ variability (Figure 1).

[10] As previously illustrated by Novelli et al. [1998], the amplitude of the measured $\mathrm{CO}$ seasonal cycle shows an inter-hemispheric gradient with regional differences reflecting variations in the magnitude and distance from the major sources and sink (reaction with $\mathrm{OH}$ ) locations (Figure 2). For our subset of stations, the amplitude of the seasonal cycle lies in the 58 to 92 ppbv range for the STM, SHM, UTA and GMI stations whereas in the southern hemisphere marine stations, far from any sources (SMO, PSA), the seasonal cycle amplitude does not exceed $27 \mathrm{ppbv}$ (Table S2).

[11] The IAV was estimated by calculating each year the 'residuals' from the smoothly varying periodic seasonal cycle. The absolute area of the residual time series was then divided by the area of the mean seasonal cycle, giving a percentage of IAV (IAV index) at each site (Table S2). For northern and tropical marine boundary layer sites, the observed mean IAV index over 1997-2001 reaches roughly

\footnotetext{
${ }^{1}$ Auxiliary material data sets are available at $\mathrm{ftp} / / / \mathrm{ftp}$.agu.org/apend/gl/ 2007gl030231. Other auxiliary material files are in the HTML.
}

$11 \%$ (Table S2 and Figure 2). In the southern hemisphere, at high latitude sites representative of the background atmosphere (CGO, PSA, SYO, HBA, SPO), lower IAV indices are observed $(<5 \%)$. Conversely, at continental sites located downwind of industrial regions (BAL, HUN, BSC TAP), the IAV index takes higher values (18 to $23 \%$ ). Regarding changes from one year to the next, the IAV indices climbed up in 1998 to twice its unperturbed value at high northern sites (SHM and STM in Table S2) in response to unusual boreal forest fire emissions [Spichtinger et al., 2004]. In fall 1998, abnormal CO mixing ratios in excess of 60 to 100 ppbv over the mean seasonal cycle were generally recorded at high northern latitude sites (ALT, STM, ZEP, CBA, BRW, ICE and STM) and, to a lesser extent, at northern mid-latitude sites (UUM and UTA).

[12] In the tropics, unusually high CO mixing ratios were observed between mid-summer 1997 and fall 1998, reflecting intense emissions in Amazonia, southern Africa and especially in Indonesia during the El Niño event [Hauglustaine et al., 1999]. The SEY station (Indian Ocean) recorded an increase of 75 ppbv above mean seasonal levels in October and November 1997, yielding an IAV index of $25 \%$ for that year. The westward export of Indonesian fire emissions over the Pacific ocean was also reinforced by the reversed trade winds associated with El Niño. At the GMI site (central Pacific), the observed CO levels increased dramatically from September 1997 to March 1998 by 20 to 40 ppbv [see also Duncan et al., 2003]. At SMO (Southern Pacific), the highest $\mathrm{CO}$ residual anomaly was recorded from September to December 1997 when the ITCZ is located in the northern hemisphere, bringing to the sites air masses emanating from the southeastern Asian fires and entrained by the southern Pacific convergence zone (SPCZ). It leads to a positive IAV index of $13 \%$ during 1997, against a usual mean IAV index value of $8 \%$ over $1997-2001$. In the southern extra-tropics, the surface CO seasonal cycle did not change abnormally in 1998 (6-7\% instead of $4.5 \%$ usually) since the transport of biomass burning plumes at these locations takes place in altitude with minor influence at surface sites [e.g., Pak et al., 2003; Freitas et al., 2006].

[13] The BB_VAR and BB_CLIM simulations were then used to separate the role of biomass burning emissions and atmospheric transport on the surface CO IAV. First, we checked on the model's ability to reproduce both the seasonal cycle and the CO IAV. The BB_VAR simulation results were thus compared to the observations both in terms of correlation and variability (Figure S2). The correlations for residuals alone are given in Table S2. For $83 \%$ of the sites, the model-data correlation coefficient ( $\mathrm{r}$ ) is higher than 0.6 . The standard deviation in observations is on average underestimated by $18 \%$. This underestimation can be in part due to the use of a coarse resolution model and of climatological emissions for anthropogenic, biogenic and oceanic sources.

[14] At northern stations, the CO residual enhancements are explained by polluted episodes in winter (see STM in Figure 1), and by biomass burning sporadic contributions in summer (see SHM in Figure 1). During such elevated CO episodes which are faithfully reproduced by the BB_VAR simulation, the corresponding NOAA flask data were often statistically flagged as 'non background' because of their high deviation $(3 \sigma)$ from the seasonal mean [Novelli et al., 

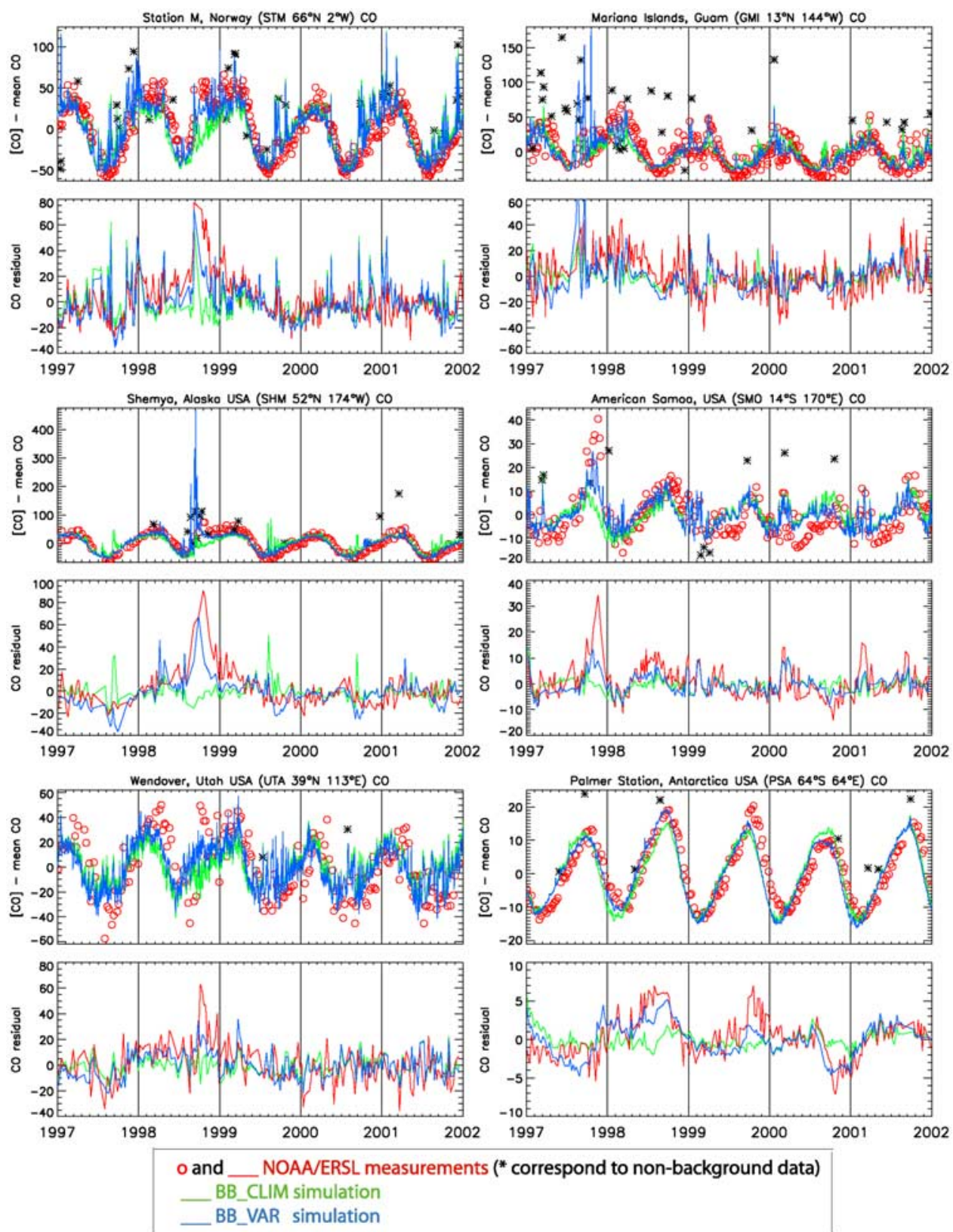

Figure 1. Time evolution of $\mathrm{CO}(\mathrm{vmr}-5$ year mean) and its residual from the mean seasonal cycle (vmr-mean-mean seasonal cycle) for NOAA/ERSL observations and LMDz-INCA simulations at six CMDL stations. For time evolution of $\mathrm{CO}$, the modeled daily means are used whereas observations are kept on their own temporal resolution. For the residuals, the model results are selected on the exact days of flask measurements. BB_CLIM = climatological biomass burning emissions and variable winds; BB_VAR = interannually variable biomass burning fluxes and variable winds.

1998]. This suggests that such 'non-background' data corresponding to long-lasting pollution transport episodes are representative enough to be useful for inferring $\mathrm{CO}$ emissions in inverse modeling studies. For Station M (Norwegian Sea), the observations show the highest interannual variability in 1998 whereas the model leads to a maximum in 1997. This error is partly due to non background air masses with high $\mathrm{CO}$ levels which are simulated in 1997 but excluded from the NOAA observations. Hence, such global simulations could be helpful for refining the "non-background" criteria at NOAA sites.

[15] Figure 1 shows that the BB_VAR simulation is also able to reproduce (1) the long duration El Niño episode with high CO values spanning from mid-1997 to mid-1998 at GMI (Central Pacific), (2) the CO peaks caused by Siberian forest fires in summer 1998 at SHM (Aleutians) (also at ALT, ZEP, BRW, CBA in Figure S1), and (3) the long range transport of fire emissions at a mid-latitude site (UTA). So the BB_VAR reference simulation reproduces correctly both the seasonal and the synoptic high-frequency $\mathrm{CO}$ variations at most sites.

[16] Comparisons of the 5 year averaged BB_VAR and BB_CLIM results (Table S2) show that, except for stations located at high southern latitudes, the climate variability explains a large part of the CO IAV. Over 1997-2001, the variations in the GFEDv2 biomass burning emissions alone 

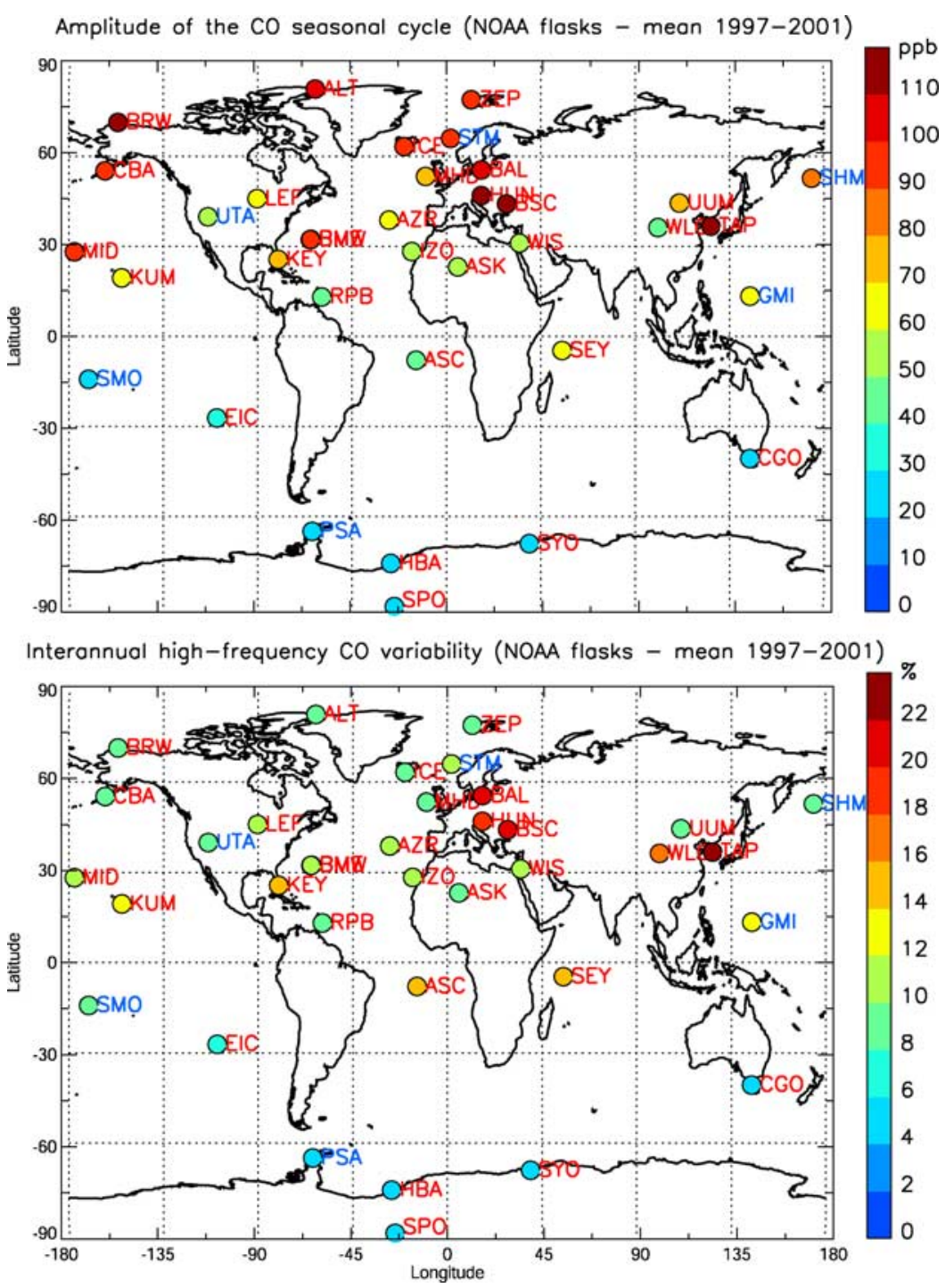

Figure 2. (top) Amplitude of the CO seasonal cycle (maximum-minimum) and (bottom) mean IAV index at $36 \mathrm{NOAA} /$ ERSL stations. The six stations mainly used in the paper are labelled in blue.

contribute for only $10 \%$ to the modeled CO IAV at a high northern latitude station such as STM. It contributes between 25 to $51 \%$ for GMI, UTA, SMO and SHM, and reaches up to $55 \%$ for high southern latitude sites. However, during the particular years of 1997 and 1998, biomass burning became a dominant source of variability, exceeding $70 \%$ at northern stations SHM, CBA and ALT in 1998 and $50 \%$ at tropical stations GMI, SEY and EIC in 1997, and KUM and EIC in 1998. An additional simulation was performed to separate the direct effect of climate changes (e.g. transport, precipitation and cloud cover) from its indirect effect on the oxidizing capacity through water vapor variability. For this run, we impose the 2001 water vapour distributions every year in the chemistry. This simulation shows that the main effect of climate interannual variability on CO IAV is dominated by variations of the general circulation, the cloud distribution and the precipitation with impact of water vapor changes on $\mathrm{OH}$ playing a minor role. Regarding the IAV index averaged over the 5 years, this effect of $\mathrm{OH}$ variability on chemical lifetime (via the water vapour) is indeed responsible for less than $5 \%$ of the CO IAV except for 4 stations (AZR, MID, KUM, and GMI) where it can change by up to $8.7 \%$. Looking in more detail at the yearly IAV index, we find that only five stations have both an IAV index higher than $5 \%$ and a significantly different yearly IAV index value (i.e. 10 to $13 \%$ of modification compared to BB_CLIM) for specific years. As a consequence, we conclude that the main effect of varying climate on CO IAV is not due to the OH IAV linked to modification of water vapour content.

\section{Conclusions}

[17] In this study, we compared multi-year time series of $\mathrm{CO}$ flask measurements with the results of a global chemistry transport model in order to investigate the relative contributions of biomass burning emissions and atmospheric climate variability to the tropospheric composition interannual variability (IAV). The consistency of the simulations was first evaluated by comparison with NOAA/ ESRL network measurements. Over the Antarctic, the amplitude of the surface CO seasonal cycle as well as the 
interannual variability are weak. At high latitude stations both in the southern and northern hemispheres, variations in biomass burning emissions and meteorology contribute a similar amount to the $\mathrm{CO}$ interannual variability. In the tropics, meteorological variability explains most of the CO variability $(50-90 \%$ on average over the considered 5 years). Only during specific episodes, do biomass burning emissions play a dominant role in $\mathrm{CO}$ variations. In particular, in 1997-1998, the El Niño event led to anomalous climate conditions such as important widespread dryness and, as a consequence, induced a positive wildfire emission anomaly. The induced CO increase in the tropics and in boreal regions can only be simulated by considering the large IAV of biomass burning emissions.

[18] We conclude that modeling investigations of the IAV of $\mathrm{CO}$ can not rely on a repeating set of single year meteorology. Furthermore, the recent development of biomass burning emission datasets, based on available remote sensing information, greatly improves the simulation CO IAV.

[19] Acknowledgments. The authors are particularly thankful to G. R. van der Werf (Vrije Universiteit Amsterdam), G.J. Collatz (NASA Goddard Space Flight Center), L. Giglio (SSAI, Maryland), J.T. Randerson (California Institute of Technology) and P.S. Kasibhatla (Duke University) for providing GFED-v2 biomass burning emissions data (http://www.geo. vu.nl/users/gwerf/GFED.htm). We also acknowledge P.C. Novelli, K.A. Masarie, E.J. Dlugokencky, K. Thomming, P.M. Lang and P.P. Tans (Climate Monitoring and Diagnostics Laboratory) for providing the NOAA/ESRL flask measurements (http://www.cmdl.noaa.gov/ccgg/ flask.html) and curve fitting routines to analyze these data. This study was partly funded by the European project RETRO (contract EVK2-CT2002-00170).

\section{References}

Andreae, M. O., and P. Merlet (2001), Emission of trace gases and aerosols from biomass burning, Global Biogeochem. Cycles, 15, 955-966.

Arino, O., J.-M. Rosaz, and P. Goloub (1999), The ATSR World Fire Atlas: A synergy with 'Polder' aerosol products, Earth Obs. Q., 64, 1-6.

Bousquet, P., et al. (2006), Contribution of anthropogenic and natural sources to atmospheric methane variability, Nature, 443, 439-443, doi: $10.1038 /$ nature 05132 .

Dlugokencky, E. J., L. P. Steele, P. M. Lang, and K. A. Masarie (1994), The growth rate and distribution of atmospheric methane, J. Geophys. Res., 99(D8), 17,021-17,043, doi:10.1029/94JD01245.

Dlugokencky, E. J., R. C. Myers, P. M. Lang, K. A. Masarie, A. M. Crotwell, K. W. Thoning, B. D. Hall, J. W. Elkins, and L. P. Steele (2005), Conversion of NOAA atmospheric dry air $\mathrm{CH}_{4}$ mole fractions to a gravimetrically prepared standard scale, J. Geophys. Res., 110, D18306, doi:10.1029/2005JD006035.

Duncan, B. N., I. Bey, M. Chin, L. J. Mickley, T. D. Fairlie, R. V. Martin, and H. Matsueda (2003), Indonesian wildfires of 1997: Impact on tropospheric chemistry, J. Geophys. Res., 108(D15), 4458, doi:10.1029/ 2002JD003195.

Folberth, G., D. A. Hauglustaine, J. Lathière, and F. Brocheton (2006), Impact of biogenic hydrocarbons on tropospheric chemistry: Results from a global chemistry-climate model, Atmos. Chem. Phys., 6, 2273-2319.

Freitas, S. R., K. M. Longo, and M. O. Andreae (2006), Impact of including the plume rise of vegetation fires in numerical simulations of associated atmospheric pollutants, Geophys. Res. Lett., 33, L17808, doi:10.1029/ 2006GL026608.
Giglio, L., J. D. Kendall, and R. Mack (2003), A multi-year active fire dataset for the tropics derived from the TRMM VIRS, Int. J. Remote Sens., 24(22), 4505-4525.

Hauglustaine, D. A., G. P. Brasseur, and J. S. Levine (1999), A sensitivity simulation of tropospheric ozone changes due to the 1997 Indonesian fire emissions, Geophys. Res. Lett., 26, 3305-3308.

Hauglustaine, D. A., F. Hourdin, L. Jourdain, M.-A. Filiberti, S. Walters, J.-F. Lamarque, and E. Holland (2004), Interactive chemistry in the Laboratoire de Météorologie Dynamique general circulation model: Description and background tropospheric chemistry evaluation, J. Geophys. Res., 109, D04314, doi:10.1029/2003JD003957.

Justice, C. O., L. Giglio, S. Korontzi, J. Owens, J. T. Morisette, D. Roy, J. Descloitres, S. Alleaume, F. Petitcolin, and Y. Kaufman (2002), The MODIS fire products, Remote Sens. Environ., 83(1-2), 244-262.

Langenfelds, R. L., R. J. Francey, B. C. Pak, L. P. Steele, J. Lloyd, C. M. Trudinger, and C. E. Allison (2002), Interannual growth rate variations of atmospheric $\mathrm{CO}_{2}$ and its $\delta^{13} \mathrm{C}, \mathrm{H}_{2}, \mathrm{CH}_{4}$, and $\mathrm{CO}$ between 1992 and 1999 linked to biomass burning, Global Biogeochem. Cycles, 16(3), 1048, doi:10.1029/2001GB001466.

Novelli, P. C., K. A. Masarie, and P. M. Lang (1998), Distributions and recent changes in carbon monoxide in the lower troposphere, J. Geophys. Res., 103(D15), 19,015-19,034, doi:10.1029/98JD01366.

Novelli, P. C., K. A. Masarie, P. M. Lang, B. D. Hall, R. C. Myers, and J. W. Elkins (2003), Re-analysis of tropospheric CO trends: Effects of the 1997-1998 wild fires, J. Geophys. Res., 108(D15), 4464, doi:10.1029/ 2002JD003031.

Pak, B. C., et al. (2003), Measurements of biomass burning influences in the troposphere over southeast Australia during the SAFARI 2000 dry season campaign, J. Geophys. Res., 108(D13), 8480, doi:10.1029/ 2002JD002343.

Potter, C. S., J. T. Randerson, C. B. Field, P. A. Matson, P. M. Vitousek, H. A. Mooney, and S. A. Klooster (1993), Terrestrial Ecosystem Production: A process model based on global satellite and surface data, Global Biogeochem. Cycles, 7(4), 811-841.

Ramaswamy, V., O. Boucher, J. Haigh, D. Hauglustaine, J. Haywood, G. Myhre, T. Nakajima, G. Y. Shi, and S. Solomon (2001), Radiative forcing of climate change, in Climate Change 2001: The Scientific Basis, edited by J. T. Houghton et al., pp. 349-416, Cambridge Univ. Press, New York.

Spichtinger, N., R. Damoah, S. Eckhardt, C. Forster, P. James, S. Beirle, T. Marbach, T. Wagner, P. C. Novelli, and A. Stohl (2004), Boreal forest fires in 1997 and 1998: A seasonal comparison using transport model simulations and measurement data, Atmos. Chem. Phys., 4, $1857-1868$.

Thoning, K. W., P. P. Tans, and W. D. Komhyr (1989), Atmospheric carbon dioxide at Mauna Loa Observatory: 2. Analysis of the NOAA/GMCC data, 1974-1985, J. Geophys. Res., 94(D6), 8549-8565, doi:10.1029/ 89JD00315.

Uppala, S. M., et al. (2005), The ERA-40 re-analysis, Q. J. R. Meteorol. Soc., 131(612), 2961-3012.

van der Werf, G. R., J. T. Randerson, G. J. Collatz, L. Giglio, P. S. Kasibhatla, A. Avelino, S. C. Olsen, and E. S. Kasischke (2004), Continental-scale partitioning of fire emissions during the 1997-2001 El Niño/La Niña period, Science, 303, 73-76.

van der Werf, G. R., J. T. Randerson, L. Giglio, G. J. Collatz, P. S. Kasibhatla, and A. F. Arellano Jr. (2006), Interannual variability of global biomass burning emissions from 1997 to 2004, Atmos. Chem. Phys., 6, 34233441 .

Wolter, K., and M. S. Timlin (1998), Measuring the strength of ENSO: How does 1997/98 rank?, Weather, 53, 315-324.

P. Ciais, D. A. Hauglustaine, and S. Szopa, Laboratoire des Sciences du Climat et de l'Environnement, Institut Pierre-Simon Laplace, CEA, CNRS, UVSQ, CEN Saclay, Orme des Merisier, F-91191 Gif-sur-Yvette, France. (sophie.szopa@1sce.ipsl.fr) 